\title{
Effect of Foliar Spray of Chemicals on Flowering and Fruiting in Litchi
}

\author{
Amrendra Kumar*, Sanjay Kumar Singh, S.D. Pandey, R.K. Patel and Vishal Nath
}

ICAR-National Research Centre on Litchi, Muzaffarpur- 842002, Bihar, India

*Corresponding author

\section{A B S T R A C T}

\begin{tabular}{l} 
Ke y w o r d s \\
Ethrel, Flowering, \\
Fruit Quality, \\
litchi, di-potassium \\
phosphate, mono- \\
potassium \\
Phosphate, \\
Potassium Nitrate, \\
Yield. \\
\hline Article Info \\
\hline $\begin{array}{l}\text { Accepted: } \\
12 \text { April } 2017 \\
\text { Available Online: } \\
10 \text { May } 2017\end{array}$ \\
\hline
\end{tabular}

\section{Keywords}

Ethrel, Flowering, Fruit Quality, itchi, di-potassium potassium Phosphate Potassium Nitrate, Article Info

Accepted: April 2017 10 May 2017

\section{Introduction}

Bihar is known as hub of litchi production not only in India but also in the world due to its quality fruit. Entire country people desire to taste this fascinating fruit having unique fragrance and high demand during the season. The plant is highly specific to climatic condition and soil requirement and probably due to which its cultivation is restricted to the few countries in the world. Fruit yield of litchi in different production belts is irregular and below the potential bearing capacity of the trees. Usually, litchi plants take longer gestation period (> 15 years) to reach at consistent and regular bearing stage. In the juvenile stage of plant growths (7-14 years tree age), trees showed erratic and irregular behavior of bearing due to continuous growth flushes after harvest and changing environment conditions and thus farmers suffers for a long period in order to get regular fruiting (Kumar et al., 2015). As the litchi tree require low temperature to induce flowering and subsequently fruiting (Menzel and Simpson, 1995). This is possible only by maintaining a balance between continuous vegetative growth in juvenile litchi trees and 
degree of dormancy to initiate flower bud formation and subsequently initiation of flowering panicle. Dormancy in litchi is apparently influenced by dry weather or recurring period of relatively cold weather. The main objectives of litchi growers are to harvest maximum quantity of marketable fruits as the lowest investment cost.

Potassium, is an essential macro-element required in large amounts for normal plant growth and development involved in many physiological processes, water relations, photosynthesis, assimilate transport and enzyme activation which have direct consequences on crop productivity. When potassium uptake is lower than demand, foliar potassium is mobilized to the fruit, which is detrimental for plant growth and fruit set and quality (Besford and Maw, 1975). Pre-harvest sprays of potassium and growth regulators are one of the most important practices of the new strategies applied in the integrated fruit production systems, improving fruit quality (Mandal et al., 2012). Application of ethrel @ $1,000 \mathrm{ppm}$, which could not only remove winter flushes but also dropped mature leaves, thereby affecting plant growth and development and sometimes bring flowering in coming season. Many investigations reported the use of potassium salts $\left(\mathrm{K}_{2} \mathrm{HPO}_{4}\right.$ or $\mathrm{KNO}_{3}$ ) as a chemical agent for induction of plant resistance and induction of flowering. This $[\mathrm{K}+]$ cation plays a major role in: enzyme activation, protein synthesis, stomatal function, stabilization of internal $\mathrm{pH}$, photosynthesis, turgor-related processes and transport of metabolites (Abd El Rahman and Hoda, 2016).

Response of various growth promoting chemicals and regulators on regulation of flowering and fruiting have been studied by various workers in litchi (Mishra et al., 2012; Zhang et al., 2002). The foliar spray of $\mathrm{KH}_{2} \mathrm{PO}_{4}(1 \%)+\mathrm{KNO}_{3}(1 \%)$ seems to be beneficial for increasing the flowering, fruit set and improving the fruit size and weight of mango cv. Keshar (Garad et al., 2013). The information on use of growth regulators and their influence on shoot behavior, flowering panicle induction, fruit yield and their inter relation is lacking particularly in juvenile litchi orchard. The aim of the present study was to test the effects of foliar spraying of KNO3, ethrel, potassium di-hidrogen phosphate, di-potassium hydrogen phosphate either alone or in combination of two or more on the flowering, yield, fruit quality characteristics of litchi fruits.

\section{Materials and Methods}

The experiment was conducted in 10-12 years old litchi orchard during 2014-2016 consecutively for 2 years at Research Farm of ICAR-NRC on Litchi Muzaffarpur, Bihar located at $210 \mathrm{~m}$ MSL. The litchi cv. Shahi was planted at a spacing of $8.25 \mathrm{~m} \times 8.25 \mathrm{~m}$ which accommodates 144 plants per ha. The experiment was laid out in randomized block design (RBD) comprising of 9 treatments $\mathrm{T} 1$ : $\mathrm{KNO}_{3}(1 \%) ; \mathrm{T} 2: \mathrm{K}_{2} \mathrm{HPO}_{4}(1 \%) ; \mathrm{T} 3: \mathrm{KH}_{2} \mathrm{PO}_{4}$ (1\%); T4: $\mathrm{K}_{2} \mathrm{HPO}_{4}(2 \%) ; \mathrm{T} 5: \mathrm{KH} 2 \mathrm{PO} 4(2 \%)$; T6: $\mathrm{K}_{2} \mathrm{HPO}_{4}(1 \%)+\mathrm{KNO} 3(1 \%), \mathrm{T} 7: \mathrm{KH}_{2} \mathrm{PO}_{4}$ $(1 \%)+\mathrm{KNO}_{3}(1 \%)$; T8:Ethrel (400 ppm) and T9: Control (water spray) with three replication. A back-held spray pump was used for foliar application of the chemicals. After each treatment, the pump was washed thoroughly.

A teaspoon of commercial washing powder was added as a wetting agent for effective result and for improvement in absorption. Distilled water containing a comparable amount of wetting agent was sprayed on the plants in the controlled treatment. All foliar spraying was carried out early in the morning. Four spray of each chemical was applied during 1st week of every month starting from October to January (at 30 days interval). Standard cultural practices were followed to grow the litchi crops. The experimental field was sandy loam in texture, alkaline in 
reaction with low to medium in fertility status.

The observation on per cent shoot flowered was recorded on the basis of shoot flowered divided by total shoots tagged and multiplied by 100 . Deviation in flowering was assessed through flowering time of control tree taken as bench mark and any delay or early flowering was indicated with prefix $(-$ and + , respectively) sign before numerals. Total number of flower per panicle was estimated by counting floral shoots of tagged branches in individual trees. Sex ratio was calculated by number of female flower divided by number of male flowers per panicle counted from randomly selected flowering shoot in each direction. Fruit maturity (harvest date) was determined on the basis of fruit colour developed (a bright pinkish red blush with flattened tubercles) and pulp TSS reached 18 ${ }^{\circ}$ Brix.. The average fruit weight was estimated by weighing 10 fruits in each treatment, with the help of an electronic balance measuring in grams to the third decimal place, and then converting to average fruit weight. Pulp recovery, seed weight was obtained by weighing of pulp, seed and whole fruit separately. For determination of TSS, sub-samples $(10 \mathrm{~g})$ were pressed through cheese cloth to extract the juice. Total soluble solids were determined with Erma Hand Refractometer (0-32o Brix) with necessary temperature correction. The titratable acidity percentage of juice was estimated as per AOAC (2000). TSS/acid ratio was calculated by dividing the TSS value with acidity. The data were subjected to statistical analysis as per the method of Gomez and Gomez (1984). Least significant of difference at 5\% level was used for finding the significance of differences if any, among the treatment means.

\section{Results and Discussion}

The results in table 1 clearly showed that foliar spray of various chemical had pronounced effect on shoot panicle emergence percentage and in terms of delay or advancement in flowering period, number of flowers (total, male and female) per panicle and sex ratio. More than $75 \%$ shoots showed flowering due to spray of $\mathrm{K}_{2} \mathrm{HPO}_{4}(1 \%)$ and ethrel (400 ppm). Untreated trees had only $56.17 \%$ shoot flowered during the same season. Flowering in litchi was advanced by 5.17 days in tree sprayed with ethrel (400 ppm) than normal time of panicle emergence observed (12-16 March) in control trees. Increase in number of flowers per panicle is an indicator of plants yield and ethrel (400 ppm) spray also led to rapid jump in total number of flower per panicle (182.26) followed by trees sprayed with $\mathrm{KH}_{2} \mathrm{PO}_{4}(1 \%)$. Control tree was observed to be half of total flowers per panicle recorded in tree receiving $1 \% \quad \mathrm{KH}_{2} \mathrm{PO}_{4} . \mathrm{KNO}_{3} \quad(1 \%)$ and combined spray of $\mathrm{K}_{2} \mathrm{HPO}_{4}(1 \%)+\mathrm{KNO}_{3}(1 \%)$ showed delayed flowering by 4.66 days and 3.66 days, respectively than normal flowering time.

The more numbers of shoot expressing panicle emergence may be attributed to suppression of vegetative growth which resulted into the fast maturation of twigs and stress due to application of potassium that led to more accumulation of photosynthates in twigs and leaves. $\mathrm{K}_{2} \mathrm{HPO}_{4}(1 \%$ or $2 \%)$ had least deviation in flowering time with control trees, means it doesn't have much effect on flowering time. Delay in panicle emergence under $\mathrm{KNO}_{3}(1 \%)$ spray might be due to changes in carbohydrate and mineral metabolism in the shoots. Delay in flowering in $\mathrm{KNO}_{3}$ treated plants might be due to its effect in supplementing the nitrogen to the leaves. The $\mathrm{KNO}_{3}$ treatment has been effective for stimulating flowering of mango trees that had remained vegetative well beyond normal bearing ages, for advancing the flowering and fruiting periods, and for breaking the biennial bearing habits of trees. 
Table.1 Flowering attributes affected by foliar spray of K+ ions and ethrel in litchi cv. Shahi

\begin{tabular}{|c|c|c|c|c|c|c|c|c|c|c|c|c|c|c|c|c|c|c|}
\hline \multirow[t]{2}{*}{ Treatments } & \multicolumn{3}{|c|}{ \% shoot flowered } & \multicolumn{3}{|c|}{${ }^{*}$ Flowering (days) } & \multicolumn{3}{|c|}{ Total Flowers/ panicle } & \multicolumn{3}{|c|}{ Male flowers/ panicle } & \multicolumn{3}{|c|}{ Female flowers / panicle } & \multicolumn{3}{|c|}{ Sex ratio } \\
\hline & 2015 & 2016 & Pooled & 2015 & 2016 & Pooled & 2015 & 2016 & Pooled & 2015 & 2016 & Pooled & 2015 & 2016 & Pooled & 2015 & 2016 & Pooled \\
\hline $\mathrm{KNO}_{3}(1 \%)$ & 68.33 & 80.00 & 74.17 & +4.33 & +4.66 & 4.50 & 149.33 & 154.67 & 152.00 & 98.33 & 86.00 & 92.17 & 51.00 & 68.67 & 59.83 & 0.54 & 0.80 & 0.67 \\
\hline $\mathrm{K}_{2} \mathrm{HPO}_{4}(1 \%)$ & 68.33 & 83.33 & 75.83 & +1.00 & +1.33 & 1.17 & 140.00 & 140.00 & 140.00 & 75.00 & 82.00 & 78.50 & 65.00 & 58.00 & 61.50 & 0.92 & 0.71 & 0.82 \\
\hline $\mathrm{KH}_{2} \mathrm{PO}_{4}(1 \%)$ & 70.00 & 86.67 & 78.34 & +2.00 & +2.33 & 2.17 & 168.18 & 186.33 & 177.26 & 92.18 & 89.67 & 90.92 & 76.00 & 96.67 & 86.33 & 0.81 & 1.08 & 0.95 \\
\hline $\mathrm{K}_{2} \mathrm{HPO}_{4}(2 \%)$ & 66.67 & 83.33 & 75.00 & +1.00 & +1.66 & 1.33 & 118.60 & 120.60 & 119.60 & 71.27 & 73.27 & 72.27 & 47.33 & 47.33 & 47.33 & 0.67 & 0.65 & 0.66 \\
\hline $\mathrm{KH}_{2} \mathrm{PO}_{4}(2 \%)$ & 66.67 & 78.33 & 72.50 & +3.00 & +3.00 & 3.00 & 166.87 & 160.87 & 163.87 & 93.20 & 84.87 & 89.03 & 73.67 & 76.00 & 74.84 & 0.86 & 0.97 & 0.92 \\
\hline $\begin{array}{l}\mathrm{K}_{2} \mathrm{HPO}_{4}(1 \%)+ \\
\mathrm{KNO}_{3}(1 \%)\end{array}$ & 65.00 & 75.00 & 70.00 & +2.66 & +3.00 & 2.83 & 176.27 & 162.00 & 169.14 & 111.60 & 94.67 & 103.13 & 64.67 & 67.33 & 66.00 & 0.59 & 0.73 & 0.66 \\
\hline $\begin{array}{l}\mathrm{KH}_{2} \mathrm{PO}_{4}(1 \%)+ \\
\mathrm{KNO}_{3}(1 \%)\end{array}$ & 68.33 & 71.67 & 70.00 & +3.33 & +3.66 & 3.50 & 163.00 & 156.00 & 159.50 & 84.00 & 75.67 & 79.83 & 79.00 & 80.33 & 79.67 & 0.97 & 1.09 & 1.03 \\
\hline Ethrel (400ppm) & 73.33 & 78.33 & 75.83 & -5.33 & -5.00 & -5.17 & 181.72 & 182.80 & 182.26 & 119.38 & 117.80 & 118.59 & 62.33 & 65.00 & 63.67 & 0.53 & 0.55 & 0.54 \\
\hline Control & 55.67 & 56.67 & 56.17 & 0.00 & 0.00 & 0.00 & 80.00 & 106.33 & 93.17 & 42.67 & 70.67 & 56.67 & 37.33 & 35.67 & 36.50 & 0.89 & 0.51 & 0.70 \\
\hline $\mathrm{C} \mathrm{D}(P=0.05)$ & 8.97 & 14.23 & 7.93 & -- & -- & - & 30.40 & 30.86 & 17.65 & 26.92 & 24.90 & 14.28 & 17.44 & 10.00 & 7.94 & NS & 0.25 & 0.14 \\
\hline
\end{tabular}

Table.2 Fruit yield and harvesting period affected by foliar spray of K+ ions and ethrel in litchi cv. Shahi

\begin{tabular}{|c|c|c|c|c|c|c|c|c|c|c|c|c|}
\hline \multirow[t]{2}{*}{ Treatments } & \multicolumn{3}{|c|}{ Fruit yield/ plant (kg) } & \multicolumn{3}{|c|}{ Fruit wt (g) } & \multicolumn{3}{|c|}{ Seed wt. (g) } & \multicolumn{3}{|c|}{${ }^{*}$ Harvesting ${ }^{* * *}$} \\
\hline & 2015 & 2016 & Pooled & 2015 & 2016 & Pooled & 2015 & 2016 & Pooled & 2015 & 2016 & Pooled \\
\hline $\mathrm{KNO}_{3}(1 \%)$ & 65.17 & 70.86 & 68.02 & 20.54 & 22.79 & 21.67 & 3.92 & 4.16 & 4.04 & +3.5 & +3.5 & +3.5 \\
\hline $\mathrm{K}_{2} \mathrm{HPO}_{4}(1 \%)$ & 63.28 & 66.75 & 65.02 & 18.37 & 20.59 & 19.48 & 3.31 & 3.89 & 3.60 & +5.0 & +6.5 & +5.75 \\
\hline $\mathrm{KH}_{2} \mathrm{PO}_{4}(1 \%)$ & 52.65 & 55.60 & 54.13 & 17.62 & 21.85 & 19.74 & 3.46 & 3.94 & 3.70 & +2.5 & +2.5 & +2.5 \\
\hline $\mathrm{K}_{2} \mathrm{HPO}_{4}(2 \%)$ & 54.63 & 56.65 & 55.64 & 16.96 & 21.04 & 19.00 & 3.59 & 3.70 & 3.65 & +6.5 & +7.5 & +7.0 \\
\hline $\mathrm{KH}_{2} \mathrm{PO}_{4}(2 \%)$ & 58.63 & 70.65 & 64.64 & 19.61 & 18.78 & 19.20 & 3.79 & 3.80 & 3.80 & +8.0 & +3.0 & +5.5 \\
\hline $\mathrm{K}_{2} \mathrm{HPO}_{4}(1 \%)+\mathrm{KNO}_{3}(1 \%)$ & 67.86 & 65.05 & 66.46 & 18.82 & 20.18 & 19.50 & 3.77 & 4.00 & 3.89 & +2.0 & +1.0 & +1.5 \\
\hline $\mathrm{KH}_{2} \mathrm{PO}_{4}(1 \%)+\mathrm{KNO}_{3}(1 \%)$ & 66.17 & 63.25 & 64.71 & 19.68 & 23.55 & 21.62 & 3.56 & 3.83 & 3.70 & +6.0 & +6.0 & +6.0 \\
\hline Ethrel (400ppm) & 68.33 & 72.62 & 70.48 & 19.79 & 20.79 & 20.29 & 3.88 & 3.67 & 3.78 & -7.0 & -8.0 & -7.5 \\
\hline Control & 35.16 & 32.24 & 33.70 & 17.28 & 18.50 & 17.89 & 3.67 & 4.08 & 3.88 & 0.00 & 0.00 & 0.00 \\
\hline $\mathrm{CD}(P=0.05)$ & 6.79 & 2.44 & 4.96 & 1.35 & 3.80 & 0.64 & 0.26 & 0.20 & 0.21 & -- & -- & -- \\
\hline
\end{tabular}

- sign indicate (early) and + sign indicate (delay);

*** Harvest advancement/delay was counted by considering the date of harvest of control plants. 
Int.J.Curr.Microbiol.App.Sci (2017) 6(5): 1337-1343

Table.3 Physico-chemical fruit quality parameters affected by foliar spray of K+ ions and ethrel in litchi cv. Shahi

\begin{tabular}{|c|c|c|c|c|c|c|c|c|c|c|c|c|}
\hline Treatments & \multicolumn{3}{|c|}{ Pulp recovery } & \multicolumn{3}{|c|}{ TSS ${ }^{0}$ Brix } & \multicolumn{3}{|c|}{ Acidity } & \multicolumn{3}{|c|}{ TSS/Acidity ratio } \\
\hline $\mathrm{K}_{2} \mathrm{HPO}_{4}(1 \%)$ & 58.16 & 61.00 & 59.58 & 19.38 & 19.32 & 19.35 & 0.73 & 0.70 & 0.72 & 26.51 & 27.88 & 27.20 \\
\hline $\mathrm{K}_{2} \mathrm{HPO}_{4}(2 \%)$ & 60.05 & 65.45 & 62.75 & 19.92 & 19.82 & 19.87 & 0.71 & 0.71 & 0.71 & 28.07 & 27.91 & 27.99 \\
\hline $\mathrm{KH}_{2} \mathrm{PO}_{4}(2 \%)$ & 61.47 & 62.20 & 61.84 & 18.91 & 19.72 & 19.32 & 0.75 & 0.69 & 0.72 & 25.19 & 28.75 & 26.97 \\
\hline $\mathrm{K}_{2} \mathrm{HPO}_{4}(1 \%)+\mathrm{KNO}_{3}(1 \%)$ & 60.75 & 62.41 & 61.58 & 20.20 & 20.48 & 20.34 & 0.65 & 0.58 & 0.62 & 31.76 & 36.03 & 33.90 \\
\hline Control & 59.62 & 62.37 & 61.00 & 19.60 & 18.54 & 19.07 & 0.55 & 0.68 & 0.62 & 31.68 & 29.37 & 30.53 \\
\hline $\mathrm{CD}(P=0.05)$ & 2.12 & 3.74 & 2.73 & NS & 0.57 & 0.97 & 0.07 & 0.06 & 0.16 & 8.25 & 9.86 & 6.63 \\
\hline
\end{tabular}


Kumar et al., (2015) also got advanced fruit maturity in litchi by 7 days by spray of 400 ppm ethrel and 4 days by spray of $1 \% \mathrm{KNO}_{3}$. The sex ratio, number of flower per panicle (male and female flowers both) of litchi increased significantly with foliar application of various chemicals either alone or in combination. The sex ratio in trees sprayed with $\mathrm{KH}_{2} \mathrm{PO}_{4}(1 \%)+\mathrm{KNO}_{3}(1 \%)$ improved by almost 50 percent over control trees (1.03 and 0.70 , respectively) due to less number of male flower per panicles (79.83) in former treatment. Control trees not only had least number of male flowers per panicle (56.67) but also had less number of female flowers per panicle (36.50). Spray of ethrel (400 ppm) has least sex ratio due to very large no. of male flower per panicle (118.59) while control trees had lowest number of female flowers per panicles (36.50). However, number of female flower/ panicle was maximum (86.33) trees sprayed with $\mathrm{KH}_{2} \mathrm{PO}_{4}$ $(1 \%)$ and at par with $\mathrm{K}_{2} \mathrm{HPO}_{4}(1 \%)+\mathrm{KNO}_{3}$ (1\%) (Table 1).

\section{References}

Abd El-Rahman, G.F. and Hoda, M. Mohamed. 2016. Physiological Studies on Improving Fruit Quality of valencia Orange Fruits. Global J. Biol. Agri. Health Sci., 5(2): 93101.

A.O.A.C. 2000. Official Methods of Analysis.17th edition, Association of Official Analytical Chemist, Washington DC.

Ashraf, M.Y., A. Gul., M. Ashraf, F. Hussain and G. Ebert. 2010. Improvement in yield and quality of Kinnow (Citrus deliciosa $\mathrm{x}$ Citrus nobilis) by potassium fertilization. J. Plant Nutrition, 33: 1625-1637.

Baiea, M.H.M., El-Sharony, T.F., Eman, A.A. and Abd. El- Moneim. 2015. Effect of different forms of potassium on growth, yield and fruit quality of mango cv. Hindi, Int. J. Chem. Tech. Res., 8(4): 1582-1587.
Ban, T., Kugishima, M., Ogata, T., Shiozaki, S., Horiuchi, S., and Ueda, H. 2007. Effect of ethephon (2- chloroethylphosphonic acid) on the fruit ripening characters of rabbiteye blueberry. Scientia Horti., 112: 278-281.

Besford, R.T. and Maw, G.A. 1975. Effects of potassium nutrition on tomato plant growth and fruit development. Plant Sci., 42: 395-412

Garad, B.V., Jogdand, S.M., More V. and KulKarni, S.S. 2013. Effect of chemicals on flowering and fruiting in mango (Mangifera indica L.) cv. Keshar. Ecol. Environ. Conservation, 19(3): 835-838.

Gomez, A.A. and Gomez, K.A. 1984. Statistical Procedures for Agricultural Research. John Wiley \& Sons Inc, New York p680.

Kumar, M.A. and Reddy, Y.N. 2008. Preliminary investigations on the effect of foliar spray of chemicals on flowering and fruiting characters of mango $\mathrm{cv}$. Baneshan. Indian J. Agri. Res., 42(3): 164-170.

Kumar, A., Pandey, S.D. Patel, R.K., Singh, S. K., Srivastava, K., and Nath, V. 2015. Induction of flowering by use of chemicals and cincturing in 'Shahi' litchi. The Ecoscan: Special Issue, 7: 493-496.

Menzel, C.M. and Simpson, D.R. 1995. Temperature above 20 0C reduce flowering in lychee (Litchi chinensis Sonn). J. Horticultural Sci., 70: 981-987.

Mishra, D.S., Kumar, P. and Kumar, R. 2012. Effect of GA3 and BA on fruit weight, quality and ripening of Rose Scented litchi. Hortflora Res. Spectrum, 1: 80-82.

Misra, D.S. and Pal, Mahesh. 2012. Extending harvesting period of litchi (Litchi chinensis Sonn.) through chemicals application. HortFlora Res. Spectrum, 1(3): 235-238.

Qiu, J.D., Luo, X.Z. and Wu, D.Y. 2001. Regulation of flower bud differentiation in longan. Acta Horticulturae, 558: 225228

Reddy, Y.T.N. and Kurien, R.M. 2012. Effect of pruning and chemicals on flowering 
and fruit yield in mango cv. Alphonso, $J$. Horticultural Sci., 7(1): 85-87.

Saleh, M.M.S., Ashour, N.E., El-Sheikh, M.H. and Eman, A.A. Abd El-Monem. 2007. Foliar sprays of potassium di-hydrogen phosphate and their impact on yield, AmEurasian J. Agri. Environ. Sci., 2(2): 133140.
Zaied, N.S., Khafagy, S.A.A. and Saleh, M. A. 2006. Effect of Nitrogen and Potassium fertilization on vegetative growth, fruit set and quality of Washington Navel Orange trees. J. Appl. Sci. Res., 2(11): 851-857.

Zhang, W.S., Gong, Y. Z, Shen, W L, Yong, W. S. and Duan, Z. S. 2002. Effect of spraying PP333 for modulating the blossom period, China Fruits, 4: 30-31.

\section{How to cite this article:}

Amrendra Kumar and Vishal Nath. 2017. Effect of Foliar Spray of Chemicals on Flowering and Fruiting in Litchi. Int.J.Curr.Microbiol.App.Sci. 6(5): 1337-1343. doi: https://doi.org/10.20546/ijcmas.2017.605.145 